Article

\title{
Sewage Sludge Thermal Treatment Technology Selection by Utilizing the Analytical Hierarchy Process
}

\author{
Dinko Đurđević $^{1, *(\mathbb{D}, \text { Maja Trstenjak }}{ }^{2}$ and Ivona Hulenić ${ }^{1}$ \\ 1 Energy Institute Hrvoje Požar, Savska cesta 163, 10000 Zagreb, Croatia; iivic@eihp.hr \\ 2 Faculty of Mechanical Engineering and Naval Architecture, University of Zagreb, Ivana Lučića 5, \\ 10002 Zagreb, Croatia; maja.trstenjak@fsb.hr \\ * Correspondence: ddurdevic@eihp.hr
}

Received: 30 March 2020; Accepted: 26 April 2020; Published: 28 April 2020

check for updates

\begin{abstract}
Sewage sludge management has gained significance in the last several years, due to its nutrient and energy content. However, technology selection is one of the greater challenges because it is not possible to implement a technology that covers all the requirements of the considered environments. Consequently, this paper shows an example of the utilization of an analytical hierarchy process, as a decision-making tool in terms of technology selection, for sewage sludge management in Rijeka, Croatia. The criteria structuring and evaluation process with the description of several possible alternatives for thermal treatment technologies are defined within this research. For the case of Rijeka, the best and most suitable technology for sewage sludge treatment is gasification, which coincides with the results obtained from the analysis of the literature review. According to the results in this paper, the possibilities of the use of this scientific method on the national level for the selection of sewage sludge treatment technology should be considered, due to the simplicity of its use and capability of its adaptation to various situations and areas.
\end{abstract}

Keywords: sewage sludge; analytical hierarchy process; thermal treatment; energy recovery; decision support systems

\section{Introduction}

An increase of the population and urbanization has contributed to a significant increase of generated sewage sludge. The annual production of sewage sludge is constantly growing and will continue to grow in the future. The produced amount of sewage sludge in the European Union (EU) in 2010 was estimated as 11.5 million tons of dry matter (DM) and is expected to rise to 13.0 million tons $\mathrm{DM}$ in 2020 [1]. In the EU, the production of sewage sludge that is generated in primary, secondary, and tertiary treatment in wastewater treatment plants (WWTPs) amounts to an average of $90 \mathrm{~g}$ daily per capita [2]. In order to solve this problem, many EU countries are intensively working on the development of new process technologies for the treatment of sewage sludge and are developing processes in order to close the linearity of waste production and implement a circular economy of waste management. Although sewage sludge represents only 1-2 vol.\% of treated wastewater, its management is very complex and treatment costs amount to $20-60 \%$ of WWTP's total operating costs [3].

Sewage sludge is a complex heterogenous mixture of microorganisms; undigested organic matter such as paper; vegetable residues or feces; inorganic materials; and moisture [4]. Even though the sludge content and characteristics can be determined for wastewater entering the WWTP through parameters, such as the biological oxygen demand, total suspended solids, dissolved solids, volatile 
suspended solids, alkalinity, nitrogen, phosphorus, chemical oxygen demand, etc. [5,6], it is very difficult to construct a universal plant that can treat all types of sludge in the same manner. Moreover, the selection of technology for sewage sludge treatment needs to take into account several factors that considerably affect its end product, energy generation, and environmental impacts.

The choice of technology of sewage sludge treatment needs to be based on its environmental impact, i.e., the selected technology needs to eliminate (or at least reduce) the adverse environmental impact and tend to create a positive impact on the environment and human health. It also needs to be suitable for the area where it is located, due to factors of climate, water consumption, urbanization levels, etc., which can impact the aforementioned parameters. The main methods for sewage sludge management currently present in the EU are landfilling, soil application, and incineration, which are used for the treatment of almost $90 \%$ of the generated sewage sludge. Moreover, sewage sludge discharge in oceans and seas (after treatment, mostly with grates) and landfilling are practices that will soon be prohibited. However, almost $35-40 \%$ of the sewage sludge in Europe is treated this way $[7,8]$. In this context, thermal transformation of sewage sludge is gaining importance, especially for locations that cannot utilize the sludge for agricultural or similar purposes. Although there are other advanced technologies available for sludge treatment, incineration and co-incineration are currently the most used and acceptable treatments for sewage sludge management [8].

However, during wastewater treatment and the management of output streams, there is a problem concerning a large number of parameters in the system and their interrelations. Therefore, it is necessary to find a way to select a waste management method that is simple and simultaneously fulfils all requirements for acceptable waste management: socio-economic, environmental, technical, and geographical. For this purpose, the multicriteria decision-making (MCDM) method is used. MCDM is a decision-making process used in the presence of multiple, and in most cases, conflicting criteria [9-11].

MCDM is used for many purposes: from site selection to assisting decision-makers in selecting a specific waste treatment technology. In this case, MDCM is used for the purpose of technology selection for sewage sludge energy recovery. There are several studies that have considered sewage sludge as an alternative energy source, which include MDCM in the selection process. Kurniawan et al. [12] considered incineration, pyrolysis, gasification, anaerobic digestion (AD), and pelletization as processes for energy recovery from sewage sludge. Adar et al. [13] used SWOT (strengths, weaknesses, opportunities, threats) analysis to consider the optimal method for sustainable sewage sludge management, taking into account $\mathrm{AD}$, incineration, gasification, pyrolysis, and supercritical water gasification (SCWG) processes. They also used MDCM analysis to select a specific technology. In some studies, life cycle assessment was used, as a method to review the sewage sludge management system as a whole $[14,15]$.

Decision-making can be done in combination with various models; however, for the purpose of energy recovery technology selection, the analytic hierarchy process (AHP) model and Expert Choice software (Expert Choice, Arlington, TX, USA) are mostly utilized. Investigations, case studies, and analyses have mostly been done for modelling solid waste management and wastewater treatment, e.g., WWTP site selection [16,17], how to improve the enhancement of wastewater treatment [18-20], selection of a wastewater treatment process [21,22], selection of a solid waste management option [23,24], etc. An et al. [25] conducted a study that prioritized the alternative technologies for the treatment of urban sewage sludge (composting, incineration, and resource utilization). Kelessidis [26] used the AHP model to select the optimal treatment method of sewage sludge in Greece, which was also the case in Hong Kong [27].

In accordance with the aforementioned studies, AHP was used in this paper for the purpose of sewage sludge thermal treatment technology selection for the example of Rijeka and it was expected that WWTP should be constructed on the location. 


\section{State of Art: Republic of Croatia and Rijeka}

The Republic of Croatia currently has $43 \%$ of the population connected to the public sewage system and only around $27 \%$ of the wastewater is treated [28]. More than half of the wastewater and sewage sludge are produced in the four major agglomerations (Zagreb, Split, Rijeka, and Osijek), as shown in Figure 1. Croatia's regulations are completely harmonized with the provisions of the Urban Wastewater Treatment Directive (91/271/EEC), and full implementation is expected by 2023. This will lead to a larger number of WWTPs that will produce a significant increase in the amounts of sewage sludge, which needs to be managed and treated.

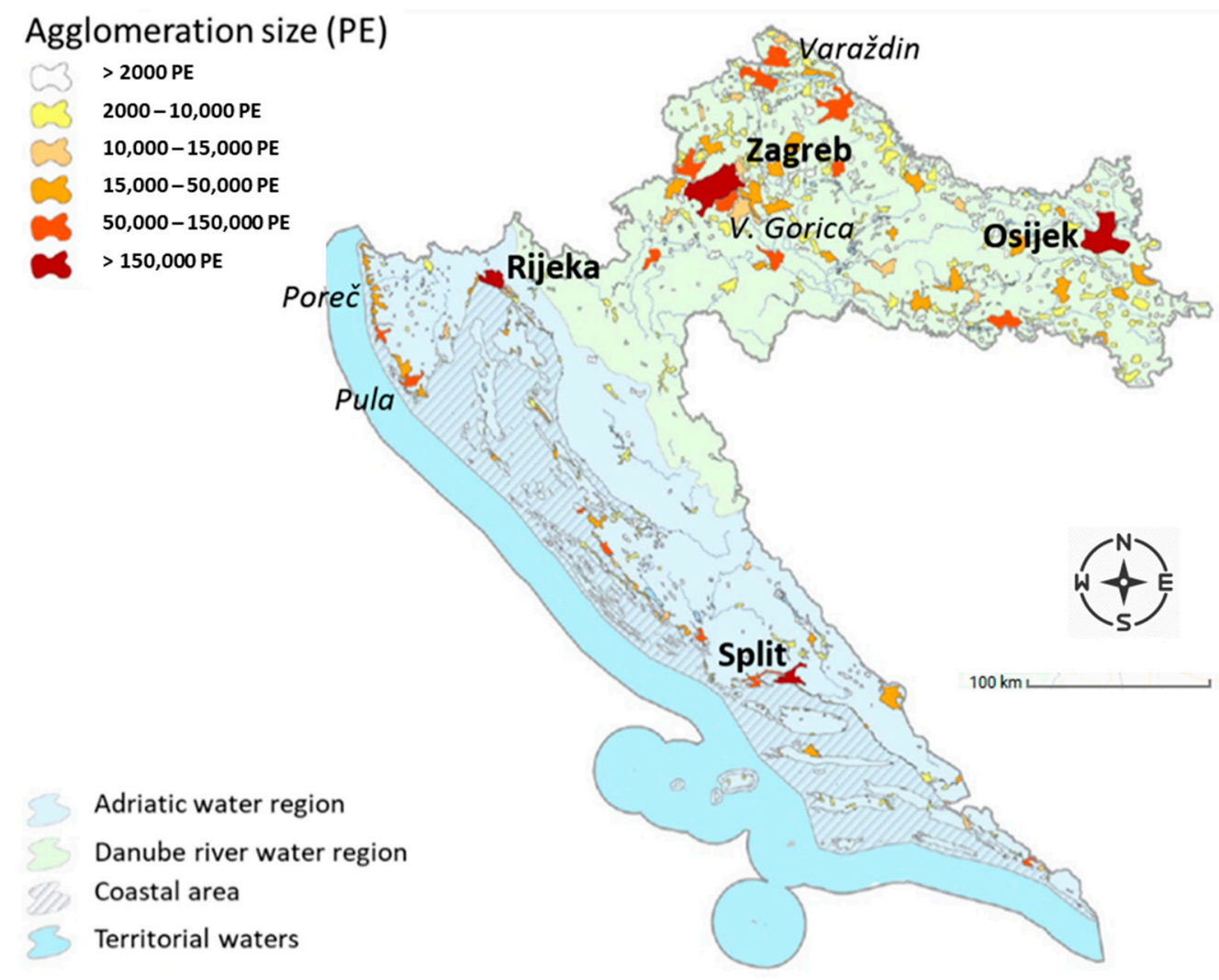

Figure 1. Spatial arrangement of agglomerations in Croatia.

This paper investigated the situation in the city of Rijeka, in Primorje-Gorski Kotar County. Rijeka currently contains a WWTP with mechanical pre-treatment, after which wastewater is released to the sea (WWTP Delta), which has been operational since 1994 and sized to a 540,000 population equivalent (PE), from which the wastewater is released to the sea after treatment.

However, WWTPs operating in larger urban agglomerations are also subject to oscillations in hydraulic and pollutant loads, although to a smaller extent than those operating in touristic agglomerations. For example, the wastewater properties at the existing WWTP in Rijeka (pre-treatment only), collected as $24-\mathrm{h}$ composite samples during three days in 2017, are given in Table 1 . These values need to be within the limits of the minimum required pollutant removal rates for WWTPs in Croatia (Table 2). 
Table 1. Wastewater properties in the WWTP Rijeka (preliminary treatment) in 2017.

\begin{tabular}{|c|c|c|c|c|c|c|}
\hline \multirow{2}{*}{ Parameter } & \multicolumn{2}{|c|}{7 February 2017} & \multicolumn{2}{|c|}{6 June 2017} & \multicolumn{2}{|c|}{9 October 2017} \\
\hline & Inlet & Outlet & Inlet & Outlet & Inlet & Outlet \\
\hline Hydraulic load (m³/day) & \multicolumn{2}{|c|}{33,437} & \multicolumn{2}{|c|}{41,472} & \multicolumn{2}{|c|}{36,461} \\
\hline Temperature $\left({ }^{\circ} \mathrm{C}\right)$ & \multicolumn{2}{|c|}{7.8} & \multicolumn{2}{|c|}{22.3} & \multicolumn{2}{|c|}{15.2} \\
\hline COD $(\mathrm{mg} / \mathrm{L})$ & 775 & 271 & 803 & 486 & 795 & 690 \\
\hline $\mathrm{BOD}_{5}(\mathrm{mg} / \mathrm{L})$ & 300 & 120 & 400 & 200 & 120 & 100 \\
\hline Suspended solids (mg/L) & 300 & 94 & 222 & 112 & 421 & 256 \\
\hline Total nitrogen, N (mg N/L) & 45.72 & 26.36 & 30.5 & 21.4 & 28.62 & 28.21 \\
\hline Total phosphorus, P (mg P/L) & 4.10 & 2.26 & 4.92 & 3.22 & 4.72 & 3.20 \\
\hline pH-value & - & 7.5 & - & 7.3 & - & 7.3 \\
\hline Electrical conductivity, S/m & - & 2.65 & - & 18.7 & - & 2.92 \\
\hline Grease, $\mathrm{mg} / \mathrm{L}$ & - & 22.1 & - & 35.2 & - & 24.9 \\
\hline Phenols, mg/L & - & 0.21 & - & 0.10 & - & 0.50 \\
\hline Detergents, mg/L & - & 5.96 & - & 3.77 & - & 5.45 \\
\hline Zinc, $\mathrm{mg} / \mathrm{L}$ & - & 0.124 & - & 0.141 & - & 0.106 \\
\hline Chromium, mg/L & - & 0.008 & - & 0.002 & - & 0.003 \\
\hline Lead, mg/L & - & 0.004 & - & 0.014 & - & 0.011 \\
\hline Total coliforms, N/100 mL & - & $1.0 \times 10^{7}$ & - & $1.4 \times 10^{7}$ & - & $4.6 \times 10^{6}$ \\
\hline Faecal coliforms, N/100 mL & - & $3.5 \times 10^{5}$ & - & $9.2 \times 10^{4}$ & - & $6.8 \times 10^{5}$ \\
\hline
\end{tabular}

Table 2. Minimum pollutant removal rates for WWTPs in Croatia.

\begin{tabular}{|c|c|c|}
\hline Parameter & Emission Limit Value & Minimum Removal Rate \\
\hline \multicolumn{3}{|l|}{ Primary treatment: } \\
\hline COD & - & $20 \%$ \\
\hline $\mathrm{BOD}_{5}$ & - & $20 \%$ \\
\hline TSS & - & $50 \%$ \\
\hline \multicolumn{3}{|l|}{ Secondary treatment: } \\
\hline COD & $125 \mathrm{mg} \mathrm{O}_{2} / \mathrm{L}$ & $75 \%$ \\
\hline $\mathrm{BOD}_{5}$ & $25 \mathrm{mg} \mathrm{O}_{2} / \mathrm{L}$ & $70 \%$ \\
\hline TSS & $35 \mathrm{mg} / \mathrm{L}$ & $90 \%$ \\
\hline Tertiary treatment: & $\mathrm{PE}<100,000$ & \\
\hline Total N & $15 \mathrm{mg} / \mathrm{L}$ & $70 \%$ \\
\hline Total P & $2 \mathrm{mg} / \mathrm{L}$ & $80 \%$ \\
\hline
\end{tabular}

Although the current system satisfies the minimum removal rates for WWTPs in Croatia, an upgrade is required in order to reduce the pollutants and satisfy the upcoming regulations that will be stricter in the field of environment protection and the growing amounts of wastewater.

Therefore, as a second final phase of the WWTP upgrade, Rijeka will implement a physicochemical and biological treatment, with a planned total load of 200,000 PE. The location for WWTP Rijeka is described in general development plans (GenDP), which determines an area of 2.2 ha $\left(22,000 \mathrm{~m}^{2}\right)$ for WWTP. However, only $50 \%$ of the determined area is set for construction purposes and the WWTP is designed to cover an area of around $9700 \mathrm{~m}^{2}$ (Figure 2), which includes all the required equipment to treat wastewater and produced sewage sludge [29].

The operation of WWTP Rijeka is divided in four activities:

1. Mechanical treatment-contains coarse screens, input pumping station, fine sieves, aerated sand-grease trap, and primary precipitator;

2. Biological treatment—contains a biologically aerated filter;

3. Sewage sludge treatment—contains sludge thickener and container, anaerobic digestors and digestate container, mechanical sludge dehydration, mechanical sludge drying, and dry sludge storage;

4. Submarine outfall—contains pipelines that discharge treated water in the sea. 
The produced sewage sludge will be treated through the AD process, in order to reduce the biological contamination of the surrounding area, when storing the remaining waste from the process (sludge/digestate). Depending on the storage capacity for digestate and the digester capacity in the $\mathrm{AD}$ process, it is possible that both digestate and raw sewage sludge will be present at the same time at WWTP. Therefore, it is necessary to find a solution to treat both waste residues, if possible, and considered in this paper, in the same manner (thermal treatment). The produced biogas will be used in a cogeneration plant $(\mathrm{CHP})$, where produced thermal energy will be used to dry the by-product (digestate/sludge), while electricity will be used to power the WWTP or sold to the electrical power system.

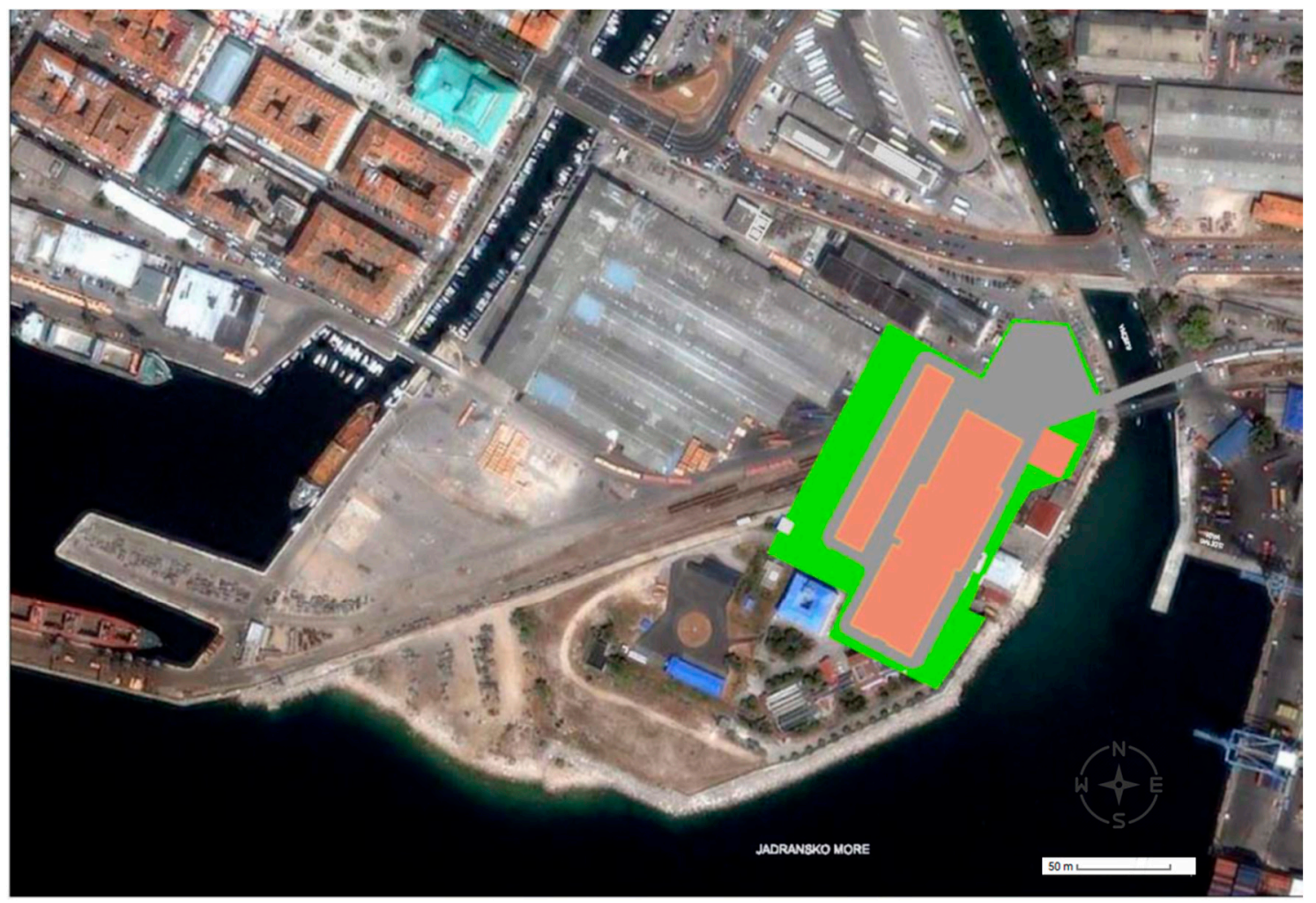

Figure 2. Location of the future WWTP Rijeka.

Produced sludge, which will be in significant amounts compared to the current situation, needs to be managed in an adequate way.

However, as Croatia is a country where sewage sludge from WWTPs is usually landfilled or transported abroad and only few WWTPs manage their sludge adequately (e.g., Zagreb and Koprivnica) [30], it is necessary to select an appropriate technology for sewage sludge management in each WWTP.

Since Rijeka is located in the coastal area of Croatia, it does not have the possibility of utilizing the generated sludge directly or digestate produced in the AD process as a low-quality fertilizer. Sewage sludge or digestate transport to other parts of Croatia where this option is possible (e.g., Slavonia) is expensive and impractical. Therefore, thermal treatment methods are considered as solutions for future sludge problems (either in raw or digestate form), that will occur in Rijeka when WWTP is constructed and operational.

Some of the commercial thermal methods will be described in the following section, which are selected by the authors as possible technologies utilized in Rijeka (based on the situation in Rijeka and future plans for wastewater treatment sector), due to their similarities with regions where they are utilized [31,32]. 


\section{Possible Thermal Methods for Sewage Sludge Management in Rijeka}

The technologies of thermal treatment of sewage sludge have been extensively researched. Based on the overview of these studies and existing commercial plants that are operational [33-35], the four most common and utilized thermal technologies were selected for review in this paper. Technologies considered as alternatives belong to the sewage sludge thermal treatment category: incineration, gasification, pyrolysis, and hydrothermal carbonization (HTC).

Incineration is currently one of the most researched and applied thermal technologies for sewage sludge treatment. The circulating fluidized bed is especially appropriate for the incineration of dried sewage sludge with a high heat calorific value [36]. The main advantages of this technology are a significant reduction of the sewage sludge volume, thermal degradation of toxic components, high energy efficiency, and relatively low investment compared to other technologies. However, the process requires a high sludge DM content, up to 35\% [37], which means that a pre-treatment is necessary (e.g., drying, pelletization, etc.). Moreover, during the incineration process, ash is produced, which can contain accumulated heavy metals from the sludge [30]. Therefore, it requires appropriate treatment in order to prevent pollution of the environment.

Pyrolysis is a chemical degradation process during high temperatures in anaerobic conditions [33]. The main products are liquid, gaseous, and solid fraction (biochar), whose ratio depends on the process parameters. In comparison to the incineration process, pyrolysis is a very endothermic process, which requires $100 \mathrm{KJ} / \mathrm{el} / \mathrm{kg}$ DM [38]. This process also requires a pre-treatment in the form of drying.

Gasification is a process very similar to pyrolysis [30]. During gasification, only one gas is produced, which can be utilized locally and generally without additional treatment. The process is conducted in the presence of air (in the form of pure oxygen or air). The total process is self-sufficient and stable, without any need for energy input [1,20].

The HTC process is a thermochemical carbonization of sewage sludge during high temperatures and without an oxygen presence. The process requires lower temperatures than pyrolysis but very high pressure $[39,40]$.

This paper investigated energy recovery from the products and the HTC of sewage sludge, and covers the scale-up and sustainability of the process for large-scale operation. This makes the process more expensive in comparison with the aforementioned alternatives [41-43]. However, the process does not require pre-treatment due to the fact that it is conducted in the presence of water. The product is hydro-char with $70 \% \mathrm{DM}$ and contains valuable nutrient but also inert heavy metals, which makes it easy to transport and usable as a fertilizer [44].

The parameters of the mentioned four technologies are shown and compared in Table 3: 
Table 3. Comparison of technologies of thermal methods for sewage sludge treatment $[33,35,40,45-47]$.

\begin{tabular}{|c|c|c|c|c|}
\hline Parameter & Incineration & Pyrolysis & Gasification & HTC \\
\hline Temperature $\left({ }^{\circ} \mathrm{C}\right)$ & $850-1000$ & $300-900$ & $400-850$ & $180-250$ \\
\hline Pressure $(\mathrm{MPa})$ & Atmospheric & Atmospheric & Atmospheric & Autogenous \\
\hline Retention period $(\mathrm{h})$ & $\begin{array}{l}\text { Short (depending on presence } \\
\text { of other substrates }\end{array}$ & Short (seconds-hours) & Short (seconds-minutes) & $1-12$ \\
\hline Main products & 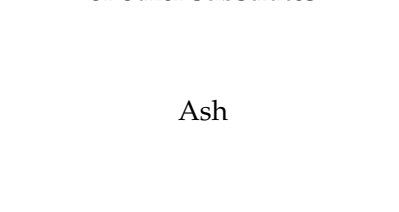 & $\begin{array}{l}\text { Gas fraction }\left(\mathrm{H}_{2}, \mathrm{CH}_{4}, \mathrm{CO}_{2} \text {, trace }\right. \\
\text { gases): heating value around } \\
15 \mathrm{MJ} / \mathrm{m}^{3} \text {. } \\
\text { Solid fraction (pyro-char). } \\
\text { Liquid fraction (mostly oils, water, tar } \\
\text { and organic compounds). }\end{array}$ & $\begin{array}{l}\text { Similar to pyrolysis, but only } \\
\text { produces one flammable gas, which } \\
\text { can be utilized locally. }\end{array}$ & Hydro-char \\
\hline $\begin{array}{l}\text { Potentially harmful } \\
\text { substances produced }\end{array}$ & $\begin{array}{l}\text { Accumulation of heavy metals } \\
\text { in ash (requires special } \\
\text { treatments of flue gases. }\end{array}$ & $\begin{array}{l}\text { Most heavy metals are completely } \\
\text { contained in solid fraction. }\end{array}$ & $\begin{array}{l}\text { Fixation of hazardous substances } \\
\text { occurs, such as } \mathrm{Cd}, \mathrm{Co}, \mathrm{As}, \mathrm{Hg} \text { in } \\
\text { char and remaining ash and slag. }\end{array}$ & $\begin{array}{l}\text { Harmful substances can be } \\
\text { produced during the process. Some } \\
\text { of those are benzenes, phenols, } \\
\text { furans, aldehydes, and ketone. }\end{array}$ \\
\hline Other comments & $\begin{array}{c}\text { Relatively low investment } \\
\text { compared to other similar } \\
\text { technologies. } \\
\text { Requires removal of water } \\
\text { content. }\end{array}$ & Requires removal of water content. & $\begin{array}{l}\text { Fuel characteristics, such as surface } \\
\text { area, size, shape, moisture content, } \\
\text { volatile compounds and carbon } \\
\text { content can affect the process. } \\
\text { Requires removal of water content. }\end{array}$ & $\begin{array}{l}\text { HTC process is conducted in liquid } \\
\text { media, so it does not require } \\
\text { pre-treatment (drying). }\end{array}$ \\
\hline
\end{tabular}


Based on the GenDP, the remaining area for other purposes is amounted to around $1200 \mathrm{~m}^{2}$ and is limited with the plants'/buildings' height $(30 \mathrm{~m})$. Therefore, this area could be designated for sludge/digestate treatment that is planned to be transported to another waste management facility. The amount of waste generated is estimated to around $7000 \mathrm{t} / \mathrm{year}$, which includes dried sewage sludge/digestate and remains from the mechanical treatment (grates) [29]. This means that it is possible to construct only a small plant, due to the lack of raw material for energy recovery and the negative aspect of general opinion towards waste import from other municipalities.

\section{Methods: AHP Model Description}

The model was developed through the analytic hierarchy process, which is one of the most used decision support methods within the industry. It enables scenario analysis and the possibility of the teamwork of several experts at the same time, with consistent hierarchy evaluation. Its mathematical model was implemented in an Expert Choice software, which is very user-friendly and enables wide use by both experts from the field and ordinary management or workers within various organizations (utility companies, ministries, municipalities, etc.). The online teamwork possibilities improve the model and increases the accuracy of the results [48]. In the current research, AHP implementation was observed through four steps [49]:

1. Development of a hierarchical model for a decision-making problem, with criteria, sub-criteria, and alternatives.

2. Each junction of the hierarchical structure is assessed by the Saaty scale, pairwise, on the level 1 to 9 (where 1 determines equal importance and 9 the largest difference), in which each element is compared to the other directly above it, and local weights are calculated. Quantitative criteria and alternatives are evaluated with imported data, as shown in Table 3, while the evaluation of qualitative data is shown in Table 4.

3. From assessments of the relative importance elements of the relevant hierarchical level of the problem, local criteria and sub-criteria weights are calculated, which are later processed with the AHP mathematical model, which results in the decision of the best suitable alternative for the case.

4. Sensitivity analysis is conducted in the last phase of the research.

In order to select the appropriate technology in the case of Rijeka and Croatia, criteria and sub-criteria were chosen based on a literature review of the scientific papers related to laboratory and commercial utilization of incineration, pyrolysis, gasification, and HTC technologies [3,13,50-52]; the situation in Croatia regarding wastewater and sewage sludge management; and expert judgement.

The selected criteria and sub-criteria are shown in Table 4 and were chosen due to the local situation, environment, and socio-economic standards, based on the available data for Croatia and Rijeka (national statistics: [53]). 
Table 4. Layout of criteria and sub-criteria used in this paper for Rijeka and applicable for Croatia.

\begin{tabular}{|c|c|c|}
\hline Criterion & Explanation & Measure \\
\hline \multicolumn{3}{|c|}{ Technical } \\
\hline Material stabilization & $\begin{array}{l}\text { Biological stabilization of the } \\
\text { obtained products }\end{array}$ & \multirow{7}{*}{$\begin{array}{l}\text { qualitative (1-9): 1-technology does not } \\
\text { satisfy this criterion; } 5 \text {-technology partially } \\
\text { satisfies this criterion; } 9 \text {-technology } \\
\text { completely satisfies this criterion }\end{array}$} \\
\hline Reuse of energy potential & $\begin{array}{l}\text { Possibility for energy recovery of waste and } \\
\text { obtained products after waste treatment }\end{array}$ & \\
\hline $\begin{array}{l}\text { Recovery and recycling } \\
\text { of nutrients }\end{array}$ & $\begin{array}{l}\text { Possibility of recovering valuable nutrients } \\
\text { from sewage sludge (phosphorus, nitrogen, } \\
\text { potassium) via selected technology }\end{array}$ & \\
\hline $\begin{array}{c}\text { Commercially acceptable } \\
\text { products }\end{array}$ & $\begin{array}{l}\text { Production of materials that are acceptable on } \\
\text { the market as a new material for utilization }\end{array}$ & \\
\hline $\begin{array}{l}\text { Transport and storage } \\
\text { of products }\end{array}$ & $\begin{array}{l}\text { Availability and simplicity of transport and } \\
\text { storage of obtained products }\end{array}$ & \\
\hline $\begin{array}{l}\text { Greenhouse gases } \\
\text { emission reduction }\end{array}$ & $\begin{array}{c}\text { Reduction of greenhouse gas emission } \\
\text { through utilization of sewage sludge } \\
\text { treatment technology }\end{array}$ & \\
\hline Required pre-treatment & $\begin{array}{l}\text { Necessary pre-treatment of sewage sludge in } \\
\text { order to use a selected technology } \\
\text { (e.g., drying for incineration) }\end{array}$ & \\
\hline \multicolumn{3}{|c|}{ Environmental } \\
\hline $\begin{array}{l}\text { Hazardous by-products } \\
\text { and products }\end{array}$ & $\begin{array}{c}\text { Level of hazard of by-products and output } \\
\text { waste streams from the energy } \\
\text { production process }\end{array}$ & \multirow{2}{*}{$\begin{array}{l}\text { qualitative (1-9): 1-technology does not } \\
\text { satisfy this criterion; 5-technology partially } \\
\text { satisfies this criterion; } 9 \text {-technology } \\
\text { completely satisfies this criterion }\end{array}$} \\
\hline $\begin{array}{l}\text { Heavy metals content } \\
\text { in products }\end{array}$ & $\begin{array}{l}\text { The content of heavy metals in products } \\
\text { obtained from energy recovery technology }\end{array}$ & \\
\hline \multicolumn{3}{|c|}{ Socio-Economic } \\
\hline Public acceptance & $\begin{array}{l}\text { Public opinion, support and acceptance of } \\
\text { specific technology }\end{array}$ & \multirow{6}{*}{$\begin{array}{l}\text { qualitative (1-9): 1-technology does not } \\
\text { satisfy this criterion; } 5 \text {-technology partially } \\
\text { satisfies this criterion; } 9 \text {-technology } \\
\text { completely satisfies this criterion }\end{array}$} \\
\hline Contribution to society & $\begin{array}{l}\text { How can specific technology contribute to } \\
\text { employment growth, new created jobs, } \\
\text { improvement of living standard }\end{array}$ & \\
\hline Operational cost & $\begin{array}{l}\text { Cost of technology operation (e.g., utility } \\
\text { costs, required chemicals or expendable } \\
\text { materials, etc.) }\end{array}$ & \\
\hline Investment costs & $\begin{array}{l}\text { Cost of investment (e.g., price of land, } \\
\text { necessary permits, external building, office, } \\
\text { building, etc.) }\end{array}$ & \\
\hline Energy savings & $\begin{array}{l}\text { Energy saved due to energy production via } \\
\text { recovery of sewage sludge treatment }\end{array}$ & \\
\hline Required labour & $\begin{array}{l}\text { Required workforce necessary to operate the } \\
\text { facility with specific technology }\end{array}$ & \\
\hline
\end{tabular}

The measurement of criteria and sub-criteria were determined by the decision-makers and organizations that will use the AHP for the selection of sewage sludge treatment technology in their designated areas in Croatia. Due to the simplicity of the AHP method and Expert Choice software, it is possible to change the criteria and sub-criteria based on the needs and wishes of decision-makers that are conditioned by the situation in the area they wish to implement sewage sludge treatment technology.

In the case of Rijeka, the criteria and sub-criteria described in Table 4 were used. After setting the criteria and sub-criteria and selected alternatives (thermal technologies mentioned in Table 3), criteria were evaluated pairwise using a Saaty scale (Figure 3) in Expert Choice software.

The evaluation was performed based on the literature quantitative data [54,55] for each criterion and the qualitative needs of the experts from both industry and science [54-58], taking into account the environmental impact and products and by-products that are produced during thermal processes. Multiple judgments were given so the accuracy of the results was increased, with an emphasis on the consistency. 


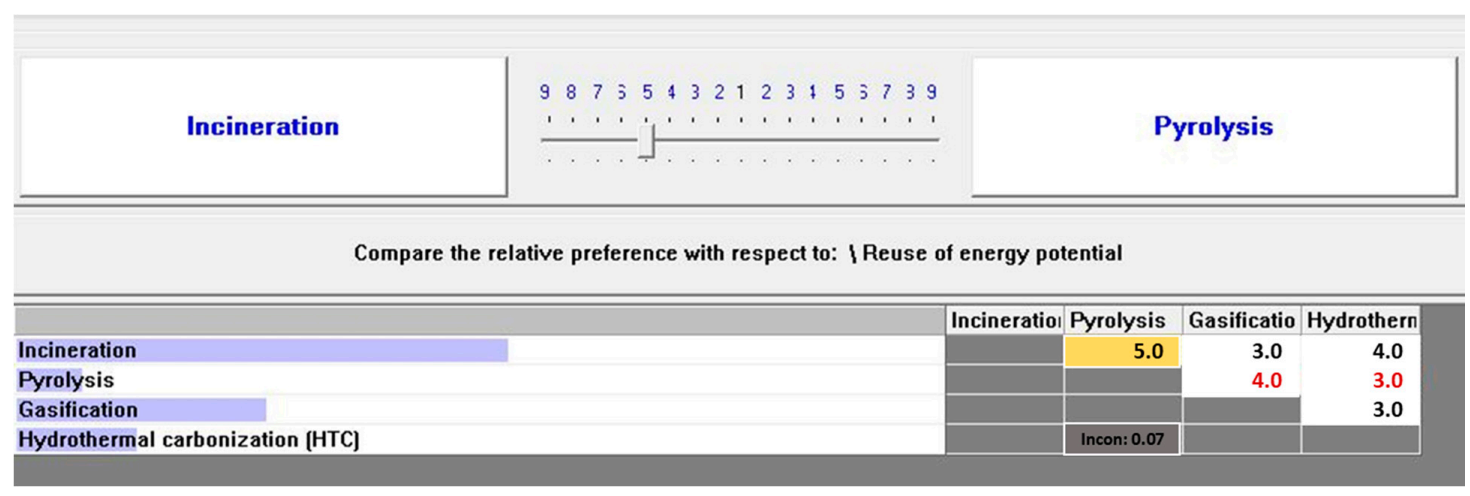

Figure 3. Example of pairwise comparison of the alternatives by a single criterion in Expert Choice (incineration vs. pyrolysis).

\section{Results and Discussion}

\subsection{Results from the AHP Model}

Considering the local community, national regulatory framework and socio-economic conditions of the observed environment, the chosen criteria are mentioned in Table 4. In order of importance, the criteria are arranged in the following order (from the most important to less important): environmental, socio-economic, and technical. This order was selected because of the ever-growing importance of environmental and socio-economic factors that are considered by decision-makers, who will use this selection method. Due to the stricter regulatory framework and increase in the awareness of the population on environmental protection and the impacts of hazardous substances on water, soil, and air, environmental criteria are becoming the most important criteria during the technology selection within waste and wastewater management $[59,60]$.

Technical criteria were considered the least important, assuming that the considered technologies are all technically highly developed and commercially available in Europe but also due to the simplicity and possibility of adaptation of commercial technologies to various conditions [3,13,50-52].

According to the results from the mathematical calculation with the decision support AHP method, with the criteria and alternative priority levels explained in Section 3, implemented in Expert Choice software, and set methodology, gasification is the best option for the considered local environment, considering the importance of the environmental criteria selected for the purpose of this paper based on the mentioned and available data. The order of the best technologies after gasification is following: HTC, pyrolysis, and incineration.

Figure 4 shows the results according to the criteria. This overview shows that gasification technology is the most suitable technology for sewage sludge thermal utilization in Rijeka, while incineration and pyrolysis follow the same pattern, considering each criterion. This means that pyrolysis is more suitable for conditions in Rijeka than incineration, regarding the selected criteria.

HTC shows deviation from the other technologies, mainly because this technology is expensive and technically quite demanding. However, as it was determined that the main importance criterion is environmental, this gives HTC technology a higher importance factor (closed process, low concentration of flue gases, possibility of water recycling, etc.) and makes it a better choice than pyrolysis or incineration.

The selected technology suitable for sewage sludge treatment in Rijeka is eligible, taking into account various factors that affected the selection process. The current WWTP in Rijeka only uses mechanical treatment of the mixed collected wastewater (sanitary and drainage wastewater), where the chemical composition of the wastewater is within the allowed limits (available data on the physicochemical composition of wastewater in WWTP Delta). This means that the production of synthetic gas, which will have less impurities, is possible, and produced bio-char can be utilized for various purposes (energy generation, fertilizer for low-quality soils, etc.). Pyrolysis, which is a 
process similar to gasification, is also applicable; however, the amount of produced synthetic gas is smaller and the energy balance benefits the gasification process more, without a negative impact on the environment and additional costs that are related to the purification of synthetic gas from the gasification process (due to high concentrations of impurities in syngas, which are not present in the case of Rijeka, as mentioned before).

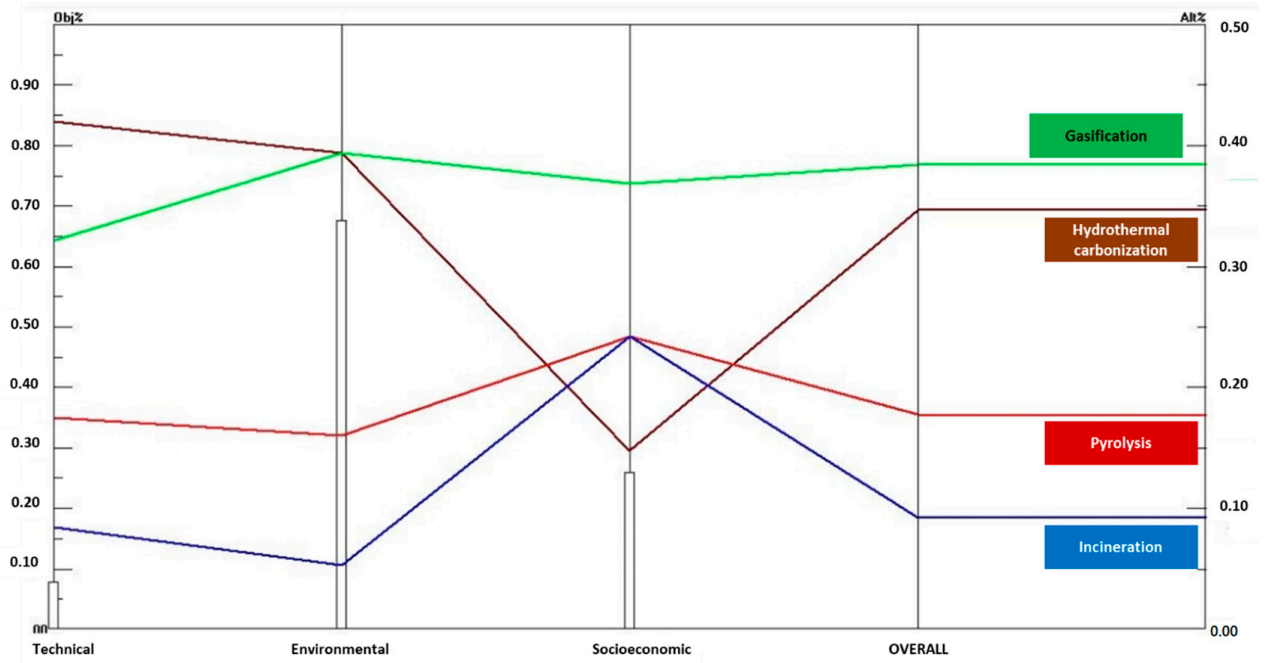

Figure 4. Overview of the results by criteria.

The final results of the software Expert Choice are shown in Figure 5. It was already mentioned that gasification technology is the best choice according to the selected criteria presented in Table 4 . However, Figure 5 provides the best overview of the difference between the selected technologies in the case of the selected criteria. This generated model with selected criteria has an overall consistency below $10 \%$ (in this case, 0.03 ), which means that it can be used in other regions and cities (other than Rijeka), which will use the same criteria and sub-criteria as was the case in this paper. This fact makes the generated model potentially applicable on the national level of the Republic of Croatia.

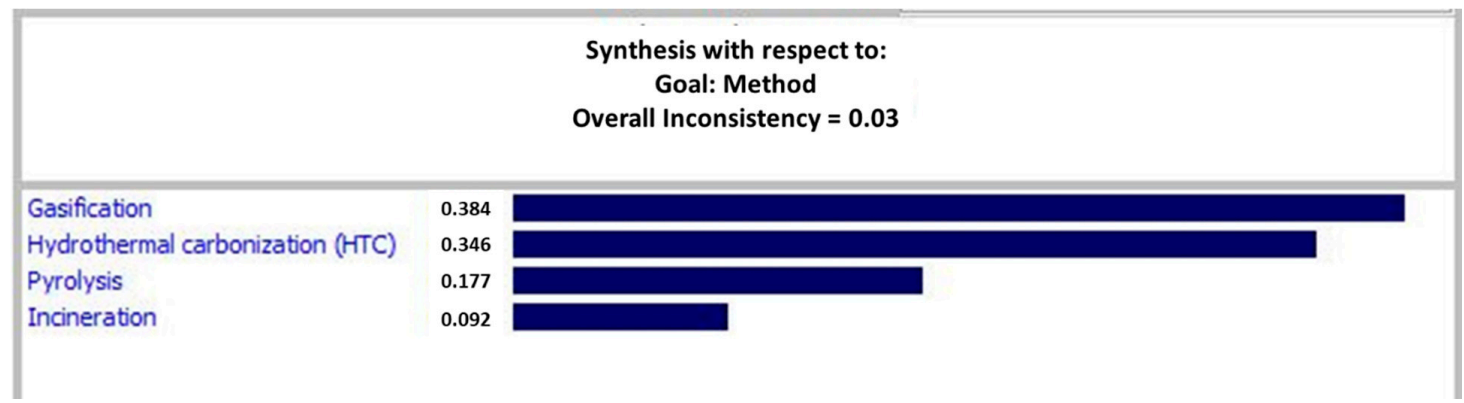

Figure 5. Final results of the AHP method in Expert Choice.

However, it was mentioned that the decision-makers who will use this model have the possibility of adjusting it to their conditions, e.g., in other parts of Croatia, creating a situation where technical criteria will play a larger role in the decision-making process than environmental criteria. Therefore, there is a possibility that the results obtained in this paper could be different in some other region or city in Croatia.

Additionally, the model uses criteria that do not require quantitative factors to select the sewage sludge treatment method. This is very important since it can result in a significant difference between the results obtained from the model and the results obtained from factual studies delivered by experts. Therefore, this model is adjusted to accommodate the needs of decision-makers; however, they do 
require basic knowledge on the situation in their geographical (municipality, county, etc.) and work area (wastewater and sewage sludge management).

Therefore, this model is applicable on the national (Croatian) level, but only taking into account the factors that will be used by decision-makers, in order to accommodate the sewage sludge thermal management technology applicable for their designated area.

\subsection{Analysis of Thermal Treatment Options for Rijeka}

The analysis of the criteria and treatments from the previous chapter is very simple and intended for decision-makers, who do not have much experience and knowledge in conducting an extensive analysis of the thermal treatment options. For a deeper analysis, the presence and knowledge of various experts that can cover the different areas of the wastewater management sector is required. Moreover, the selection of technology for sludge/digestate energy recovery is not easy, due to a large number of factors that need to be taken into account. Therefore, this chapter will present a more extensive but simplified analysis of the selection of a thermal treatment option for the city of Rijeka, based on a literature overview.

Based on the aforementioned four thermal treatment options for sewage sludge/digestate and the state of the art of Rijeka taken into account, the following results were obtained (Table 5).

Table 5. Results of the literature overview for plants with similar sewage sludge/digestate capacity as Rijeka (n.a. = not available; ${ }^{*}$ based on input of 30,000 t sewage sludge/year) [43,61-67].

\begin{tabular}{|c|c|c|c|c|}
\hline Parameter & Incineration * & Gasification & Pyrolysis & HTC \\
\hline $\begin{array}{c}\text { Capital } \\
\text { Expenditure } \\
(\mathrm{CAPEX})(\mathrm{EUR})\end{array}$ & 4 million & n.a. & 1.2 million & 315,000 \\
\hline $\begin{array}{c}\text { Operating } \\
\text { Expenditure } \\
(\mathrm{OPEX})(\mathrm{EUR})\end{array}$ & 1 million & n.a. & & \\
\hline $\begin{array}{c}\text { Gate-fee for } \\
\text { residues treatment } \\
(E U R / t)\end{array}$ & $\begin{array}{l}62 \text { (source: waste } \\
\text { management center } \\
\text { Marišćina) }\end{array}$ & $\begin{array}{l}62 \text { (source: waste } \\
\text { management center } \\
\text { Marišćina) }\end{array}$ & / & / \\
\hline Products & $\begin{array}{l}\text { ash (landfilling, filler for } \\
\text { construction industry) }\end{array}$ & synthetic gas, bio-char & $\begin{array}{l}\text { bio-char, bio-oil, } \\
\text { synthetic gas }\end{array}$ & $\begin{array}{l}\text { hydro-char, } \\
\text { wastewater that } \\
\text { can be reused in } \\
\text { the process }\end{array}$ \\
\hline Output power & $1 \mathrm{MW}_{\mathrm{th}}$ & $\begin{array}{l}0.6 \mathrm{MW}_{\mathrm{el}} \\
0.8 \mathrm{MW}_{\text {th }}\end{array}$ & n.a. & $3400 \mathrm{MWh} /$ year \\
\hline
\end{tabular}

From Table 5, it can be concluded that HTC technology is the most suitable for the case of Rijeka, due to the lowest CAPEX/OPEX values and highest power output. Moreover, the process generates minimum waste residues, all of which can be reused in the process or sold on the market as new products. However, it should be mentioned that this overview was based on a literature review and does not necessarily coincide with the real situation in Rijeka. Moreover, the analysis was based mainly on the capital and operational cost, and should include additional aspects, such as the product value on the market, complexity of the technology, used and market for the products from processes. In this manner, HTC is not feasible in Rijeka because the market for products (hydro-char) is non-existent.

Regarding the incineration method, it was determined as a non-feasible option, according to the literature review, which means that it is not applicable in Rijeka, where the annual amount of sewage sludge is predicted to be around $7000 \mathrm{t}$ DM [29].

Therefore, the pyrolysis and gasification methods are viable for the utilization of sewage sludge treatment in Rijeka. However, since these technologies are in their early commercial phases, their applicability to the case of sewage sludge treatment in Rijeka should be further researched, with concrete data from technology suppliers for the case of WWTP Rijeka. From two technologies, gasification is more applicable for the case of Rijeka, due to the fact that it generates synthetic gas and bio-char as products, from which syngas is marketable in Croatia and bio-char in neighboring countries 
(Italy, Austria, etc.). Additionally, the plant area required for the gasification process is smaller (and modular) than for the other technologies, which is applicable for the designated area determined by the general development plans for WWTP Rijeka [64]. Moreover, the required water content of the feedstock (sludge/digestate) for the gasification process is lower than for the pyrolysis process, which makes it less technologically challenging (no additional drying processes required after the treatment in WWTP) [65].

\section{Conclusions}

Sustainable sewage sludge management represents a large problem for WWTPs, due to an increase of the urban population and further strengthening of the regulatory framework related to the environment. The optimal solution for sewage sludge management depends on sludge characteristics, capital and operational costs, operational challenges and conditions, and possible utilization of the produced by-products. Appropriate solutions need to be backed up by an extensive system, which would solve economic, social, environmental, and technical questions.

The objective of this research was to select a technology for sewage sludge management in the city of Rijeka in the Republic of Croatia, based on the mentioned three criteria (environmental, socioeconomic, technical), from which the most important was the environmental one. As a decision support tool, the AHP method was selected, and implemented in Expert Choice software, which enables an easy collaboration between the science and practice (industry). As AHP is mainly a subjective method (mainly depends on the human factor and model management), scientific literature and official data were used, in order to obtain as much objectivity as possible. The results showed that in the case of Rijeka, gasification is the best and most suitable technology, due to its environmental impacts, low amount of produced (harmful) by-products, and number of job openings that it can provide. This selection was supported by a short analysis of the literature of the more extensive data (CAPEX, OPEX, products, etc.). Gasification is one of the newer advanced technologies, which has lately been greatly considered for waste and residues treatment. In this context and taking into account the current and expected situation in Rijeka, it can be considered an optimal and objective solution for sewage sludge management but also other cities in Croatia with similar conditions to Rijeka.

It is possible to obtain a decision on which technology to choose, based on the AHP method; this is a good solution for decision-makers, who have the problem of selecting the appropriate sewage sludge management technology in their regions. Based on the conducted research, this model can be used on a national level in the Republic of Croatia, due to the fact that it is easy to use and robust. It also has the option to easily form the criteria and alternative structure if decision-makers decide to modify it to fit their needs, which is the main focus of future research in the sector of Croatian sewage sludge management.

Author Contributions: Conceptualization, D.Đ.; Investigation, D.Đ. and I.H.; Methodology, D.Đ. and M.T.; Software, M.T.; Supervision, D.Đ.; Validation, D.Đ., M.T. and I.H.; Writing—original draft, D.Đ.; Writing—review \& editing, D.Đ., M.T. and I.H. All authors have read and agreed to the published version of the manuscript.

Funding: This research received no external funding

Conflicts of Interest: The authors declare no conflict of interest.

\section{References}

1. Samolada, M.; Zabaniotou, A. Comparative assessment of municipal sewage sludge incineration, gasification and pyrolysis for a sustainable sludge-to-energy management in Greece. Waste Manag. 2014, 34, 411-420. [CrossRef] [PubMed]

2. Bresters, A.; Coulomb, I.; Deak, B.; Matter, B.; Saabye, A.; Spinosa, L.; Utvik, A. Sludge Treatment and Disposal; European Environment Agency: Copenhagen, Denmark, 1997.

3. Andreoli, C.V.; Von Sperling, M.; Fernandes, F. Sludge Treatment and Disposal. Water Intell. Online 2015, 6. [CrossRef] 
4. Tyagi, K.; Lo, S. Sludge: A waste of renewable source for energy and resources recovery? Renew. Sustain. Energy Rev. 2013, 25, 708-728. [CrossRef]

5. Salgot, M.; Huertas, E.; Weber, S.; Dott, W.; Hollender, J. Wastewater reuse and risk: Definition of key objectives. Desalination 2006, 187, 29-40. [CrossRef]

6. Food and Agriculture Organization of the United Nations. 1.2 Characteristics of Wastewaters. Available online: http://www.fao.org/docrep/t0551e/t0551e03.htm\#1.2\%20characteristics\%20of\%20wastewaters (accessed on 11 April 2018).

7. Urciuolo, M.; Solimene, R.; Chirone, R.; Salatino, P. Fluidized bed combustion and fragmentation of wet sewage sludge. Exp. Therm. Fluid Sci. 2012, 43, 97-104. [CrossRef]

8. Kelessidis, A.; Stasinakis, A. Comparative study of the methods used for treatment and final disposal of sewage sludge in European countries. Waste Manag. 2012, 32, 1186-1195. [CrossRef]

9. Salminen, P.; Hollanen, J.; Lahdelma, R. Comparing multi-criteria methods in the context of environmental problems. Eur. J. Oper. Res. 1998, 104, 485-496. [CrossRef]

10. Miettinen, K.; Salminen, P. Decision-aid for discrete multiple criteria decision making problems with imprecise data. Eur. J. Oper. Res. 1999, 119, 50-60. [CrossRef]

11. Rogers, M.; Grist, B. Sidelining politicians and community groups: The site selection process for a non-hazardous landfill facility in County Galway. Munic. Eng. 2001, 145, 1-4. [CrossRef]

12. Kurniawan, T.; Hakiki, R.; Sidjabat, F.M. Wastewater sludge as an alternative energy resource: A review. J. Environ. Eng. Waste Manag. 2018, 3, 1-12. [CrossRef]

13. Adar, E.; Karatop, B.; Ince, M.; Bilgili, M.S. Comparison of methods for sustainable energy management with sewage sludge in Turkey based on SWOT-FAHP analysis. Renew. Sustain. Energy Rev. 2016, 62, 429-440. [CrossRef]

14. Cartes, J.; Neumann, P.; Hospido, A.; Vidal, G. Life cycle assessment of management alternatives for sludge from sewage treatment plants in Chile: Does advanced anaerobic digestion improve environmental performance compared to current practices? J. Mater. Cycles Waste Manag. 2018, 20, 1530-1540. [CrossRef]

15. Pradel, M.; Reverdy, A.; Richard, M.; Chabat, L. Environmental impacts of sewage sludge treatment and disposal routes: A Life Cycle Assessment perspective. In Proceedings of the 4th European Conference on Sludge Management, Izmir, Turkey, 26-27 May 2014.

16. Ansari, M.; Fahiminia, M.; Ahmadi, R.; Ahmadi, E. Evolution Site Selection by Using an Analytical Hierarchy Process for Decentralized Wastewater Treatment Plants in the City of Qom, Iran. J. Environ. Health Sustain. Dev. 2017, 2, 284-291.

17. Eiselt, H.; Marianov, V. Location modeling for municipal solid waste facilitie. Comput. Oper. Res. 2015, 62, 305-315. [CrossRef]

18. Macuada, C.; Oddershede, A.M.; Alarcón, R. Multi-criteria assessment to automate water treatment plants using the analytical hierarchy process. J. Glob. Bus. Adv. 2015, 8, 236. [CrossRef]

19. Hu, W.; Liu, G.; Tu, Y. Wastewater treatment evaluation for enterprises based on fuzzy-AHP comprehensive evaluation: A case study in industrial park in Taihu Basin, China. SpringerPlus 2016, 5, 907. [CrossRef] [PubMed]

20. Farhan, M.; Farhan, Y. A Comparative Analysis of Wastewater Minimization and Treatment Using the Analytical Hierarchy Process. In Proceedings of the 46th Annual Meeting of International Society of Beverage Technologists (ISBT), Fort Lauderdale, FL, USA, 15-18 May 1999.

21. Karimi, A.R.; Mehrdadi, N.; Hashemian, S.J.; Bidhendi, G.N.; Tavakkoli-Moghaddam, R. Selection of wastewater treatment process based on the analytical hierarchy process and fuzzy analytical hierarchy process methods. Int. J. Environ. Sci. Technol. 2011, 8, 267-280. [CrossRef]

22. Bottero, M.; Comino, E.; Riggio, V. Application of the Analytic Hierarchy Process and the Analytic Network Process for the assessment of different wastewater treatment systems. Environ. Model. Softw. 2011, 26, 1211-1224. [CrossRef]

23. Abu Qdais, H.; Alshraideh, H. Selection of management option for solid waste from olive oil industry using the analytical hierarchy process. J. Mater. Cycles Waste Manag. 2014, 18, 177-185. [CrossRef]

24. Marković, D.; Janošević, D.; Jovanović, M.; Nikolić, V. Application method for optimization in solid waste management system in the city of Niš. Facta Univ. Ser. Mech. Eng. 2010, 8, 63-76. 
25. An, D.; Xi, B.; Ren, J.; Ren, X.; Zhang, W.; Wang, Y.; Dong, L. Multi-criteria sustainability assessment of urban sludge treatment technologies: Method and case study. Resour. Conserv. Recycl. 2018, 128, 546-554. [CrossRef]

26. Kelessidis, A. Application of a Multi-Criteria Analysis Model in Decision Making for Sewage Sludge Treatment Method. In Proceedings of the 4th International Conference on Industrial and Hazardous Waste Management, Crete, Greece, 2-5 September 2014.

27. Tang, S.L.; Wong, C.L.; Ellis, K.V. An Optimization Model for the Selection of Wastewater and Sludge Treatment Alternatives. Water Environ. J. 1997, 11, 14-20. [CrossRef]

28. The Government of Republic of Croatia. Implementation Plan for Water Utility Directives; The Government of Republic of Croatia: Zagreb, Croatia, 2010.

29. Elektroprojekt. Environmental Study for the Sanitation System for Agglomeration Rijeka; Elektroprojekt: Zagreb, Croatia, 2015.

30. Đurđević, D.; Blecich, P.; Jurić, Ž. Energy Recovery from Sewage Sludge: The Case Study of Croatia. Energies 2019, 12, 1927.

31. Aniekan, I.; Ikechukwu, O. Review of Municipal Solid Waste Management Technologies and Its Practices in China and Germany. Int. J. Technol. Enhanc. Emerg. Eng. Res. 2016, 4, 1-7.

32. Franzke, U. Sewage Sludge Treatment in Large Cities Using Example of Berlin. In Waste Management; TK Verlag: Neuruppin, Germany, 2011; pp. 693-698.

33. Fytili, D.; Zabaniotou, A. Utilization of sewage sludge in EU application of old and new methods-A review. Renew. Sustain. Energy Rev. 2008, 12, 116-140. [CrossRef]

34. Agrafioti, E.; Bouras, G.; Kalderis, D.; Diamadopoulos, E. Biochar production by sewage sludge pyrolysis. J. Anal. Appl. Pyrolysis 2013, 101, 72-78. [CrossRef]

35. Stucki, M.; Eymann, L.; Gerner, G.; Hartmann, F.; Wanner, R.; Krebs, R. Hydrothermal carbonization of sewage sludge on industrial scale: Energy efficiency, environmental effects and combustion. J. Energy Chall. Mech. 2015, 2, 38-44.

36. Joint Researhc Centre. Best Available Techniques (BAT) Reference Document on Waste Incineration; JRC Science Hub: Bethesda, MD, USA, 2017.

37. Raynaud, M.; Vaxelaire, J.; Olivier, J.; Dieudé-Fauvel, E.; Baudez, J.-C. Compression dewatering of municipal activated sludge: Effects of salt and pH. Water Res. 2012, 46, 4448-4456. [CrossRef]

38. Khiari, B.; Marias, F.; Zagrouba, F.; Vaxelaire, J. Analytical study of the pyrolysis process in a wastewater treatment pilot station. Desalination 2004, 167, 39-47. [CrossRef]

39. Libra, J.; Ro, K.S.; Kammann, C.; Funke, A.; Berge, N.D.; Neubauer, Y.; Titirici, M.-M.; Fühner, C.; Bens, O.; Kern, J.; et al. Hydrothermal carbonization of biomass residuals: A comparative review of the chemistry, processes and applications of wet and dry pyrolysis. Biofuels 2011, 2, 71-106. [CrossRef]

40. Danso-Boateng, E.; Holdich, R.G.; Martin, S.J.; Shama, G.; Wheatley, A.D. Process energetics for the hydrothermal carbonisation of human faecal wastes. Energy Convers. Manag. 2015, 105, 1115-1124. [CrossRef]

41. Tumuluru, J.S. Biomass Preprocessing and Pretreatments for Production of Biofuels; CRC Press: Boca Raton, FL, USA, 2018.

42. Saba, A.; McGaughy, K.; Reza, M.T. Techno-Economic Assessment of Co-Hydrothermal Carbonization of a Coal-Mischantus Blend. Energies 2019, 12, 630. [CrossRef]

43. Lucian, M.; Fiori, L. Hydrothermal Carbonization of Waste Biomass: Process Design, Modeling, Energy Efficiency and Cost Analysis. Energies 2017, 10, 211. [CrossRef]

44. Danso-Boateng, E.; Shama, G.; Wheatley, A.; Martin, S.; Holdich, R. Hydrothermal carbonisation of sewage sludge: Effect of process conditions on product characteristics and methane production. Bioresour. Technol. 2015, 177, 318-327. [CrossRef] [PubMed]

45. Lewis, M. Sludge pyrolysis for energy recovery and pollution control. In Proceedings of the National Conference on Municipal Treatment Plant Sludge Management, Anaheim, CA, USA, 18-20 August 1975.

46. Marrero, T.W.; McAuley, B.P.; Sutterlin, W.R.; Morris, J.S.; Manahan, S.E. Fate of heavy metals and radioactive metals in gasification of sewage sludge. Waste Manag. 2004, 24, 193-198. [CrossRef]

47. Luts, D.; Devoldere, K.; Laethem, B.; Bartholomeeusen, W.; Ockier, P. Co-incineration of dried sewage sludge in coal-fired power plants: A case study. Water Sci. Technol. 2000, 42, 259-268. [CrossRef]

48. Saaty, T. Multicriteria Decision Making: The Analytic Hierarchy Process; RWS Publications: Pittsburgh, PA, USA, 1990. 
49. Sokač, D.; Ugarković, K.; Tunjić, A. Application of the Analytical hierarchy process in setting priority of the investment by software Expert Choice. In Proceedings of the International Conference on Electricity Distribution CIRED, Šibenik, Croatia, 18-21 May 2008.

50. Dušak, V.; Bagnall, R. Using AHP Method for Making a Decision on How the Management of Sewage Sludge in the Northern Croatia. J. Inf. Organ. Sci. 2017, 41, 161-170. [CrossRef]

51. Arroyo, P.; Molinos-Senante, M. Selecting appropriate wastewater treatment technologies using a choosing-by-advantages approach. Sci. Total. Environ. 2018, 625, 819-827. [CrossRef]

52. Turunen, V.; Sorvari, J.; Mikola, A. A decision support tool for selecting the optimal sewage sludge treatment. Chemosphere 2018, 193, 521-529. [CrossRef]

53. Croatian Bureau of Statistics. Statistical Yearbook of the Republic of Croatia, 2016-2018. Available online: https://www.dzs.hr/ (accessed on 24 April 2020).

54. Rolph, D.; Bogdan, Ž. Energy Recovery from Municipal Waste-Contribution to Sustainable Development of Croatia. In Proceedings of the 2nd Conference of Sustainable Development and Climate Changes, Niš, Serbia, 13-15 September 2010.

55. Boldyryev, S.; Mikulčić, H.; Krajačić, G.; Duić, N. Waste heat utilisation of Croatian cement industry accounting Total Site demands. Softw. Archit. Tools Comput. Aided Process Eng. 2016, 38, 2223-2228.

56. Matković, L. Waste and Water Management in Croatia; Embassy of Belgium, Com.: Zagreb, Croatia, 2015.

57. Nakić, D.; Vouk, D.; Štirmer, N.; Serdar, M. Management of sewage sludge-new possibilities involving partial cement. Građevinar 2018, 70, 277-286.

58. Plavac, B.; Filipan, V.; Sutlović, I.; Svetičič, J. Sustainable waste management with mechanical biological treatment and energy utilization. Teh. Vjesn. Tech. Gaz. 2017, 24, 1283-1289.

59. European Commission. Being Wise with Waste: The EU's Approach to Waste Management; Publications Office of the European Union: Brussels, Belgium, 2010.

60. European Parliament; Council of the European Union. Decision No 1386/2013/EU of the European Parliament and of the Council of 20 November 2013 on a General Union Environment Action Programme to 2020 'Living well, within the limits of our planet'. Off. J. Eur. Union 2013, 354, 171-200.

61. Lumley, N.P.; Ramey, D.F.; Prieto, A.; Braun, R.; Cath, T.Y.; Porter, J. Techno-economic analysis of wastewater sludge gasification: A decentralized urban perspective. Bioresour. Technol. 2014, 161, 385-394. [CrossRef] [PubMed]

62. Wirtha, B.; Eberhardt, G.; Lotze-Campen, H.; Erlach, B.; Rolinski, S.; Rothe, P. Hydrothermal Carbonization: Influence of plant capacity, feedstock choice and location on product cost. In Proceedings of the 19th European Biomass Conference and Exhibition, Berlin, Germany, 6-10 June 2011.

63. Oladejo, J.; Shi, K.; Luo, X.; Yang, G.; Wu, T. A Review of Sludge-to-Energy Recovery Methods. Energies 2018, 12, 60. [CrossRef]

64. Tsybina, A.; Wuensch, C. Analysis of Sewage Sludge Treatment Methods in the Context of Circular Economy. Detritus 2018, 2, 3-15. [CrossRef]

65. Kim, J.; Jeong, S. Economic and Environmental Cost Analysis of Incineration and Recovery Alternatives for Flammable Industrial Waste: The Case of South Korea. Sustainability 2017, 9, 1638.

66. TerraNova, “TerraNova Ultra,” TerraNova Energy. 2014. Available online: http://terranova-energy.com/pdf/ TNE-Brochure-2014-en.pdf (accessed on 15 April 2019).

67. Judex, J.W.; Gaiffi, M.; Burgbacher, H.C. Gasification of dried sewage sludge: Status of the demonstration and the pilot plant. Waste Manag. 2012, 32, 719-723. [CrossRef]

(C) 2020 by the authors. Licensee MDPI, Basel, Switzerland. This article is an open access article distributed under the terms and conditions of the Creative Commons Attribution (CC BY) license (http://creativecommons.org/licenses/by/4.0/). 